\title{
許容時間率を用いたダイレクトゲイン太陽熱暖房住宅評価法に関する研究 STUDY ON THE PASSIVE SOLAR HEATING DESIGN OF RESIDENTIAL BUILDINGS WITH ADAPTABLE TIME RATE ESTIMATION
}

\author{
川島宏起*1, 佐藤 誠*2, 高瀬 幸 造*3, 中川あや*1 \\ 石綿麻矢 ${ }^{* 4}$, 前 真之*5 \\ Hiroki KAWASHIMA, Makoto SATOH, Kozo TAKASE, \\ Aya NAKAGAWA, Maya ISHIWATA and Masayuki MAE
}

\begin{abstract}
On the Pacific side of Japan, we can take advantage of rich solar energy in winter times to design the low cost passive solar heating system by the direct solar gain through glazing. To keep the room air temperature warm and comfortable only by the passive way, it is important to design the balance among heat gain, heat loss, thermal mass, and thermal mass area. First, we focused on PCM (Phase Change Material), light enough for Japanese wood structure houses to have greater heat capacity, and proved its performance by the actual space experiment. Based on this result, we made the numerical model to simulate the room air temperature with PCM. Finally, we proposed an easy evaluation method to find the better combination of the four, using Southern window area to Q-value charts with adaptable time rate estimation.
\end{abstract}

\section{Keywords : Direct Solar Gain, Building Thermal Mass, Phase Change Material(PCM), Evaluation Method, Design Principle ダイレクトゲイン，身体蓄熱，潜熱蓄熱材(PCM)，評価法，設計指針}

\section{1 はじめに}

\section{1 研究の背景}

日本の戸建住宅は古来より木造を基本として発達し, 高温多湿な 夏の快適性を重視した設計手法が伝統的に取り入れられてきたが, 2010 年に施行された住宅エコポイント制度や，2020 年度までに全 ての新築住宅・建築物について省エネルギー基準への適合を段階的 に義務付ける方針を国の政策目標としていること，住宅における暖 房用エネルギー消費は東京(IV地域) 注1)のような比較的温暖な地域 であっても全体の $20 \%$ 以を占める 1)ことから，木造高断熱住宅に おける快適性と省エネルギー性を両立した暖房方法の開発とその評 価法の整備が必要である. 省エネルギーの観点から最も大切にすべ きは空を透過して室内に入射する日射熱取得（ダイレクトゲイン， 以降 DG）で, 日本の太平洋側地域の多くは冬期の日射量が豊かで あるため, 1970 年代のオイルショック以降, 太陽熱を利用した住宅 暖房技術の開発が行われてきた。 中でも DG 利用には，導人コスト が低く簡便な技術として多数の研究例えば 2) 4)がある. 昨今では熱容 量の小さい木造住宅の高断熱化が進んだことにより, 昼間の過剩な 室温上昇も懸念されており, 昼間の日射を効率良く吸熱し夜間に放 熱をする, 室内熱容量の確保のための手法が求められている.

室内熱容量確保の際には，DG をまず蓄熱体に吸熱させて昼間の 過度な温度上昇を抑制し, 高い断熱性能の躯体によって熱の損失を
減らし，蓄熱体からの放熱だけで朝方まで室温を高く保つことが理 想である. 日射熱取得のみで快適性の高いな室温変動を得るために は, 図 1 に示寸ように躯体の断熱性能, 空からの日射熱取得性能, 蓄熱体の量と敷設面積の 4 点のバランスを取る必要があり，その手 法は住まい方や地域，敷地の特性によって変わる。

熱容量を付加する手法として簡便なのは，建材として一般的なコ ンクリートを用いることだが，木造住宅の場合は重量の問題から床 面等への付加に限定されることが多い，そこで，木造に代表される 軽量建物に熱容量を付加する材料として広く研究が行われているの が潜熱蓄熱材(Phase Change Material，以降 PCM）である．PCM は製造時に任意に選択可能な相変化温度帯で融解・凝固熱を利用し て蓄熱・放熱することが可能な素材であり，中でも $20 \sim 30^{\circ} \mathrm{C}$ の温度 帯に相変化温度を持つものは, 暖房利用の際に軽量ながら大きな熱 容量を持ち得る.

PCM とDG を利用した暖房システムの既往の研究として, 射場 本，鎌田ら5)や尾崎ら 6)，Athienitis, Feldman ら 7)による潜熱蓄熱 材を練り込んだ石膏ボードや, Kuznik ら 8)によるゲル化した PCM のアルミサンドイッチパネルの室温調整性能に関する研究があげら れる、しかし，研究の主眼は限定された気象・躯体条件での性能評 価にとどまり，実際の住宅に敷設するためのガイドラインは未だ整 備の途上である。
*1 東京大学大学院工学系研究科建築学専攻 工修

*2 佐藤エネルギーリサーチ 代表取締役・博士(工学)

*3 東京理科大学理工学部建築学科 助教 · 博士 (工学)

*4 東京大学大学院工学系研究科建築学専攻 修士課程

*5 東京大学大学院工学系研究科建築学専攻 准教授・博士 (工学)
Dept. of Architecture, Grad. Sch. of Eng., the Univ. of Tokyo, M. Eng. CEO, Satoh Energy Research Co., Ltd., Dr. Eng.

Assistant Prof., Dept. of Architecture, Tokyo University of Science, Dr. Eng.

Dept. of Architecture, Grad. Sch. of Eng., the Univ. of Tokyo

Assoc. Prof., Dept. of Architecture, Grad. Sch. of Eng., the Univ. of Tokyo, Dr. Eng. 


\section{2 研究の目的と概要}

本研究では, 図 1 に示寸 4 つの要素のバランスが取れた太陽熱暖 房住宅の評価法に基づいた設計指針を提示すべく，多様な気象・敷 地条件と躯体性能の組み合わせにおける, 蓄熱体が温熱環境に与え る影響の検証と，実用上適切な蓄熱体敷設量・面積の検討を行う.

本研究のフローを図 2 に示す. 本研究では断熱境界の内側に蓄熱 体を設けるよう, 内壁の下地材と内装仕上げ材の間に蓄熱体を挿入 する仕様を前提としており，その蓄放熱性状に影響を与える要素と して, PCM の敷設量・面積とともに仕上げ材の検討を行うもので ある. 検討 2 の屋外実験装置を用いた検討ではコストや実験期間が 限られ，複数の PCM 敷設手法の検討を行うことができないため, 検討 1 で模型箱と人工太陽を用いて, 複数の PCM 敷設手法と仕上 げ材の比較検討を行うことで, 屋外実験装置に敷設する仕様を決定 する. 続く検討 3 では, 実気象条件下で観測された結果を用い, 実 験結果の再現性の高い計算モデルの構築を行い, PCM の敷設量・ 面積による温熱環境に与える影響の違いを検討する。最後に, 日本 の代表的な地域の気象条件下において, 躯体の断熱性能, 空からの 日射熱取得性能, 蓄熱体の敷設量・面積の計 4 点について, 検討 3 で作成された計算モデルを用いて複数の組み合わせの評価を行うこ とによって, 顕熱・潜熱双方の蓄熱手法における DGを用いた太陽 熱暖房住宅の評価法と設計指針の提案を行う.

\section{2. ダイレクトゲインと PCM を用いた躯体蓄熱の特性把握実験} 2. 1 検討 1 : 模型箱と人エ太陽を用いた蓄放熱性状の把握

東京大学工学部 1 号館地下に設けられた暖冷房ブースをエアコン 制御で 16 から $18^{\circ} \mathrm{C}$ に保ち, 内寸 $335 \mathrm{~mm}$ 立方体のうち 1 面を開口 として作成した模型箱を, 縦 $670 \mathrm{~mm}$ 横 $470 \mathrm{~mm}$ のすりガラスを押 し当て, 人工太陽光注2)を図 3 に示寸方式で水平照射注3)した，模型 箱の詳細平面図, 測定点を図 4 に, 実験装置, 模型箱の写真を図 5,6 に示す, 照射の強度を決めるにあっては, 実際に有り得る室温変動 の中での PCM の蓄放熱挙動を検証することを目的とし，人工太陽 光の強度はガラス透過後で $300 \mathrm{~W} / \mathrm{m}^{2}$ (ガラス面全体で $33.2 \mathrm{~W}$ ) とする ことで, 冬期の DG による室温変動を模擬した(図 7). 左が屋外実 験装置で実測された 11 月の晴れの日の室温変動を示しており, 本 実験では最寒期の 2 月を模擬するため， 2 つの月の平均気温の差を 考慮し, 最高最低ともに $7^{\circ} \mathrm{C}$ 程度低い温度変動をするものとして模 擬した。また検証には多くの実験ケースを必要としたため, 4 時間 照射・ 8 時間非照射と, 半日で 1 サイクルの実験とした. PCM は表 1 に示寸物性值で, 縦横 $300 \mathrm{~mm}$ の正方形のアルミパックに封入し たものを用い, $\mathrm{PCM}$ の潜熱の敷設熱容量を $1.4 \mathrm{MJ} /\left(\mathrm{m}^{2} \cdot \mathrm{K}\right)$ 注4) と して箱の奥面の 1 面に $15 \mathrm{~mm}$ 厚の $\mathrm{PCM}$ パックを敷設した場合, 奥 面・上面・右面の 3 面に $5 \mathrm{~mm}$ 厚を敷設した場合, PCM 敷設なしの 場合の 3 種の蓄熱方式ごとに, 熱抵抗や塗装を変えた仕上げ材 3 種 （表 2）と組み合わせ，計 9 種の実験を行うことで敷設面積や仕上 げ材により異なる PCM の蓄放熱性状を比較した。

図 8 には室内部位への入射日射量の測定值に, 表 2 の日射吸収率 を乗じた仕上げ材・部位別の表面日射吸収量を示す。すりガラスに よる拡散があるものの, 全ての仕上げ材において光源に正対する奥 面の吸収量が多い。白アルミ仕上げの場合は他壁面に比べて奥面の 吸収量は 1.6 倍, 黒アルミ仕上げの場合は 4.0 倍と, 日射吸収率が

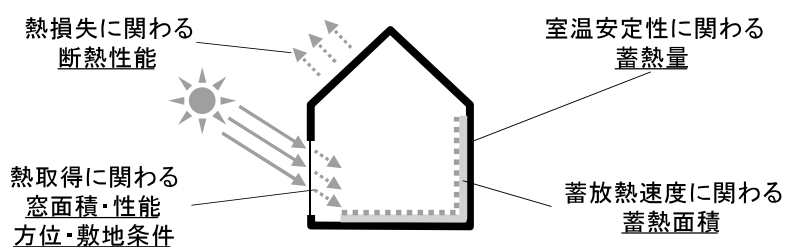

図 1 本システムでバランスを取るべき 4 つの要素

ダイレクトゲインと躯体蓄熱を用いた太陽熱暖房システムの構築

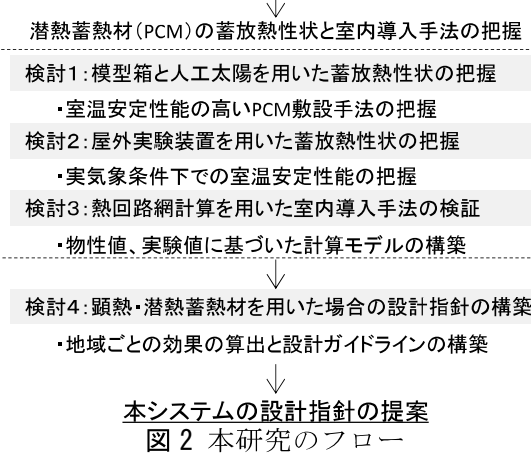

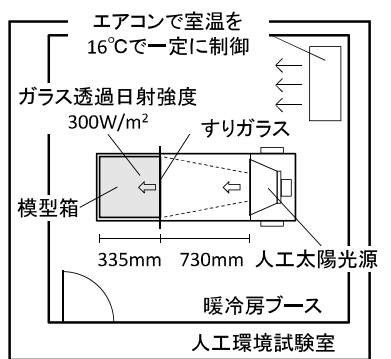

図 3 実験室平面図

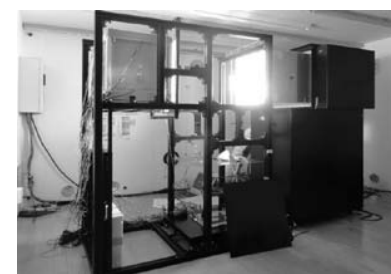

図 5 実験装置写真

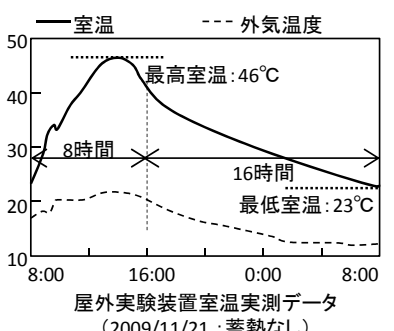

(2009/11/21: :蓄熱なし)

図 7 室温変動実測值と箱内温度の模擬

表 $1 \mathrm{PCM}$ の物性値

\begin{tabular}{|c|c|c|c|c|c|c|c|c|}
\hline \multirow{3}{*}{ PCM } & 相変化温度 & 潜熱量 & 熱伝 & 導率 & 顕熱 & 比熱 & & 度 \\
\hline & \multirow{2}{*}{${ }^{\circ} \mathrm{C}$} & \multirow{2}{*}{$\mathrm{kJ} / \mathrm{kg}$} & \multicolumn{2}{|c|}{$\mathrm{W} /(\mathrm{m} \cdot \mathrm{K})$} & \multicolumn{2}{|c|}{$\mathrm{kJ} /(\mathrm{kg} \cdot \mathrm{K})$} & \multicolumn{2}{|c|}{$\mathrm{g} / \mathrm{cm}^{3}$} \\
\hline & & & 固相 & 液相 & 固相 & 液相 & 固相 & 液相 \\
\hline 加熱 & $20-23$ & 170 & 0 & $0 ?$ & 10 & 20 & 0 & 0 \\
\hline 冷却 & $20-22$ & 170 & 0.4 & 0.2 & 1.9 & 2.6 & 0.9 & 0.8 \\
\hline
\end{tabular}

表 2 仕上げ材の物性値

\begin{tabular}{|c|c|c|c|c|c|}
\hline 仕上げ材 & \begin{tabular}{|l|} 
熱伝導率 \\
$\mathrm{W} /(\mathrm{m} \cdot \mathrm{K})$
\end{tabular} & $\begin{array}{c}\text { 日射 } \\
\text { 吸収率\% }\end{array}$ & \begin{tabular}{|l} 
熱容量 \\
$\mathrm{kJ} / \mathrm{K}$
\end{tabular} & $\begin{array}{c}\text { 熱抵抗 } \\
\left(m^{2}-K\right) / W\end{array}$ & $\begin{array}{l}\text { 厚さ } \\
\mathrm{mm}\end{array}$ \\
\hline 黒アルミ & \multirow{2}{*}{237.3} & 95.7 & \multirow{2}{*}{0.02} & \multirow{2}{*}{$8.4 \times 10^{-6}$} & \multirow{2}{*}{2} \\
\hline 白アルミ & & 17.2 & & & \\
\hline 含板 (無塗装) & 0.13 & 31.9 & 0.01 & $3.1 \times 10^{-2}$ & 4 \\
\hline
\end{tabular}


高い仕上げほど，奥面と上下左右面の日射吸収量に違いがある。こ れは, 明色の仕上げ材の場合は入射日射が他壁面へ反射することで 日射が分配されるためである. 次に, 箱内温度と PCM の床面積あ たり合計吸放熱量の時刻変動の比較結果を図 10 に示す. PCM なし の場合は黒アルミ仕上げで $38.2^{\circ} \mathrm{C}$ と, 仕上げの日射吸収率が大きい ほど箱内最高温度が高いことがわかる。これは明色の仕上げ材の場 合, 入射した人工太陽光のうちガラスを通して箱外部へ再放出され た日射量が大きいためである.また, 3 種の仕上げ材共通で, PCM3 面敷設は 1 面敷設と比較して箱内最高温度が $1.2 \sim 1.7^{\circ} \mathrm{C}$ 低下し, 非 照射 4 時間後の箱内温度が $1 \sim 1.5^{\circ} \mathrm{C}$ 上昇した。 これは, PCM 3 面敷 設は 1 面敷設と比較して, 照射時の吸熱量および非照射時の放熱量 がそれぞれ最大で $35 \sim 41 \mathrm{~W} / \mathrm{m}^{2} ， 8 \sim 15 \mathrm{~W} / \mathrm{m}^{2}$ 大きいためだと考えら れる. 仕上げ材による違いでは, 照射時では, 黒アルミ仕上げは他 と比較して吸熱量が $5 \sim 66 \mathrm{~W} / \mathrm{m}^{2}$ 大きく, 非照射時ではアルミ仕上げ は合板仕上げと比較して放熱量が $9 \sim 17 \mathrm{~W} / \mathrm{m}^{2}$ 大きい, 黒アルミ仕上 げ・ 3 面敷設では, 照射開始 2 時間半後に箱内温度の上昇が急にな った。これは奥面の $\operatorname{PCM}(5 \mathrm{~mm}$ 厚 $)$ が吸収した日射熱によって, $\mathrm{PCM}$ が完全に液相になったためであると考えられる.

次に, 各ケース・面に敷設された $\mathrm{PCM}$ 蓄放熱の短波・長波・対 流別の熱収支を図 9 に示した計算方法で算出し時間変動のグラフを 作成した(図 11)。黒アルミ仕上げ・3 面敷設の奥面 PCM について は, 照射 2 時間半後に蓄熱量が小さくなり, 仕上げ材表面の吸収日 射熱のうち PCM に蓄熱されなくなった熱量が長波・対流熱伝達成 分として箱内へ再放熱し, 箱内温度上昇の原因となっている. 一方 で，黒アルミ仕上げ・1 面敷設の場合は PCM（15mm 厚）が固相，
液相が混在した状態を維持していたとみられ，安定した蓄熱が確認 された．白アルミ仕上げの場合に対流熱伝達成分による熱取得が大 きいのは, 箱内温度と比較して表面温度が低く保たれたためである. 合板仕上げの場合に仕上げ表面で吸収される日射熱を PCM が全て 吸収することができないのは，熱抵抗が大きく,表面で吸収された熱 が箱内一再放熱されやすいためである，以上の結果から，蓄熱手法 については，一般に言われていることではあるが，敷設する PCM を厚くすること, PCM が同容量であれば敷設面積を広くすること， $\mathrm{PCM}$ 敷設箇所の内装材の日射吸収率を大きく，熱抵抗を小さくす ることが，恒温性の高い PCM 敷設手法であると確認できた。
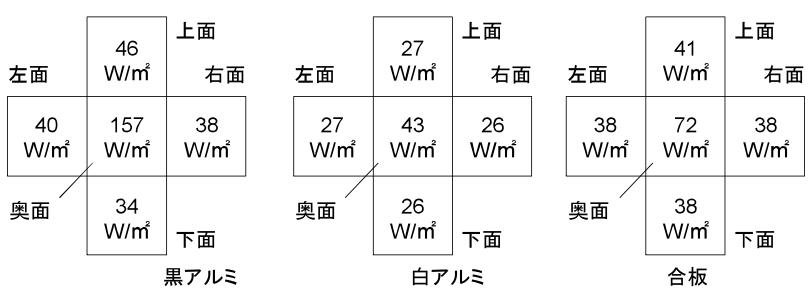

図 8 照射時各面吸収日射量展開図

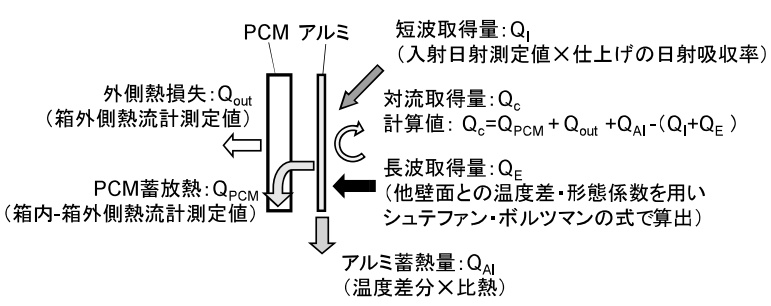

図 9 PCM 蓄放熱収支の計算の概要
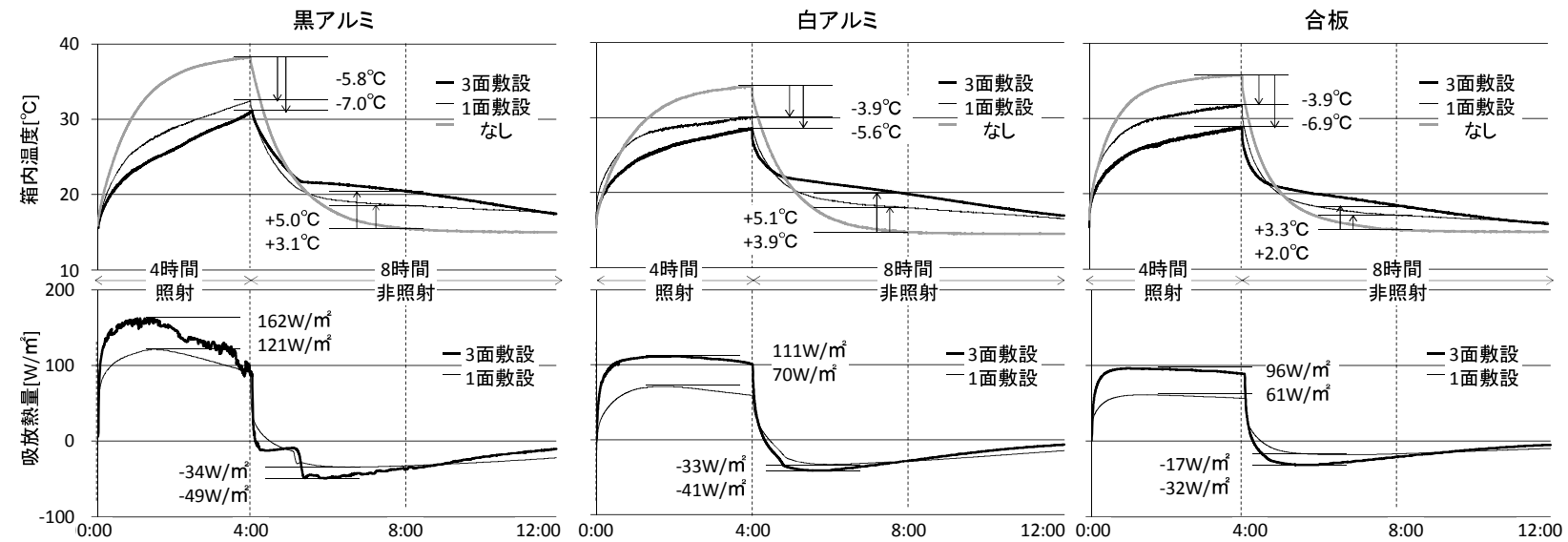

図 10 仕上げ材・蓄熱手法別箱内温度変動・PCM 蓄放熱流

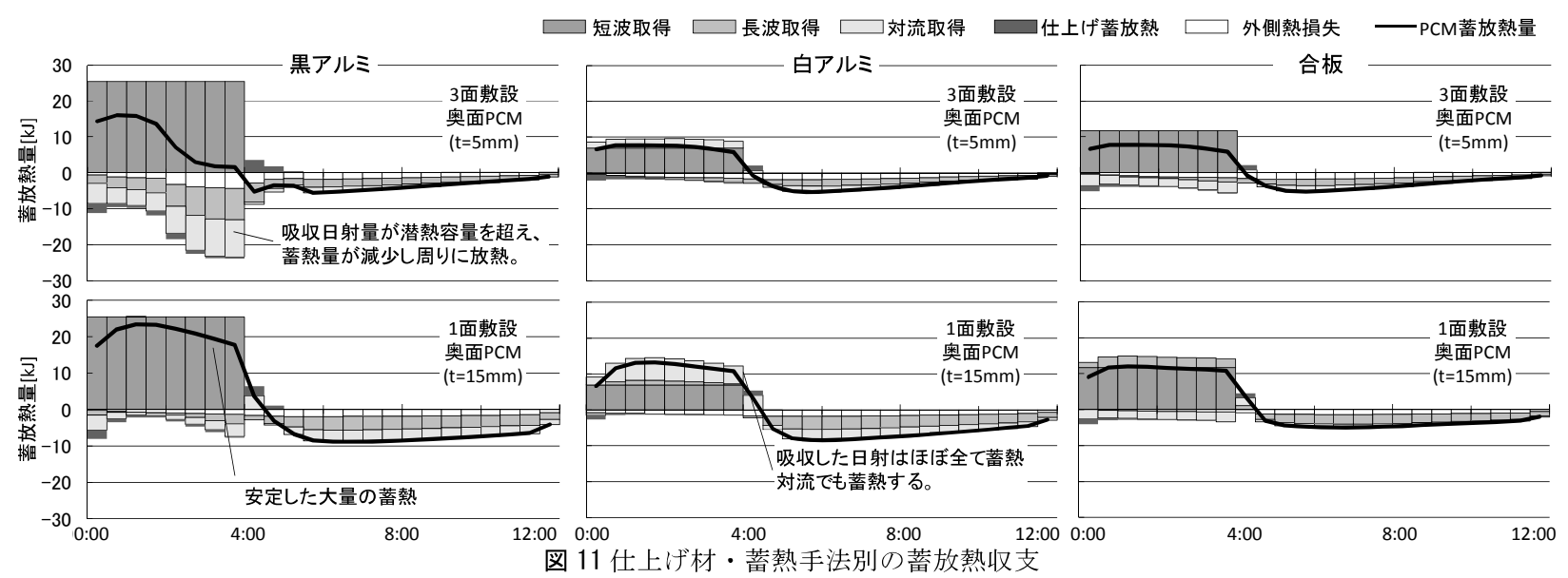




\section{2 検討 2 : 屋外実験装置を用いた蓄放熱性状の把握}

検討 1 の結果を受け, 南に正対して $6.1 \mathrm{~m}^{2}$ の開口を持つ床面積 $15.9 \mathrm{~m}^{2}$ の屋外実験装置 9)に, 検討 1 で用いた $\mathrm{PCM}$ (表 1 に示す)をア ルミパックに $10 \mathrm{~mm}$ の厚みで封入し, 熱伝導率が高く黒色に塗装し た纎維強化セメント板を仕上げ材として, 床・壁・天井で合計 32.7 $\mathrm{m}^{2}$ 敷設し, 蓄放熱性状の把握を行った. 図 12 には仕上げ材敷設前, 図 13 には敷設後の PCM と計測点注5) の様子, 表 3 には屋外実験装 置の仕様, 表 4 には外皮の構成を示寸. 実験は PCM 敷設の有無の 蓄熱条件について比較検討した。

図 14,15 に取得日射, PCM の吸放熱流, 温度の時間変動の結果 をまとめたＰPCM 敷設ありなしの比較では，PCMの日中の吸熱に
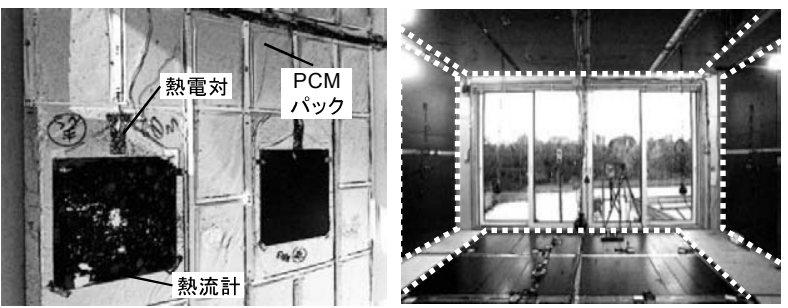

※点線で囲った範囲に PCM パックを設置し，黒色仕上げ材を施エした

図 12 壁面における PCM パック・測定点設置状況

図 13 屋外実験装置 内部設置状況

表 3 屋外実験装置仕様

\begin{tabular}{|c|c|c|c|}
\hline 床面積 & \multicolumn{3}{|c|}{$15.9 \mathrm{~m}^{2}$} \\
\hline \multirow{6}{*}{$\begin{array}{l}P C M \\
\text { 敷設 } \\
\text { 面積 }\end{array}$} & \multicolumn{3}{|c|}{$5.4 \mathrm{~m}^{2}$ (敷設率： $32.9 \%$ ) } \\
\hline & 天井 & \multicolumn{2}{|c|}{$10.8 \mathrm{~m}^{2}$ (敷設率： $65.9 \%$ ) } \\
\hline & 東壁 & \multicolumn{2}{|c|}{$6.2 \mathrm{~m}^{2}$ (敷設率: $66.7 \%$ ) } \\
\hline & 西壁 & \multicolumn{2}{|c|}{$6.1 \mathrm{~m}^{2}$ (敷設率： $65.6 \%$ ) } \\
\hline & 北壁 & \multicolumn{2}{|c|}{$4.2 \mathrm{~m}^{2}$ (敷設率： $44.7 \%$ ) } \\
\hline & 合計 & \multicolumn{2}{|c|}{$\begin{array}{r}32.7 \mathrm{~m}^{2} \text {, 熱容量: } 0.29 \mathrm{MJ} /\left(\mathrm{m}^{2}-\mathrm{K}\right) \\
\text { 敷設面積/床面積: } 199 \% \\
\end{array}$} \\
\hline \multirow{6}{*}{ 仕上げ材 } & \multirow{3}{*}{ 床 } & \multicolumn{2}{|c|}{ 高伝導フローリング $\mathrm{t}=3.0 \mathrm{~mm}$} \\
\hline & & & 吸収率: $95.7 \%$ \\
\hline & & \multicolumn{2}{|c|}{ 熱抵抗： $0.024 \mathrm{~m}^{2} \mathrm{~K} / \mathrm{W}$} \\
\hline & \multirow{3}{*}{$\begin{array}{l}\text { 天井, } \\
\text { 壁面 }\end{array}$} & \multirow{2}{*}{\multicolumn{2}{|c|}{$\begin{array}{r}\text { フレキシブルボード } \mathrm{t}=4.0 \mathrm{~mm} \\
\text { 日射吸収率: } 95.7 \%\end{array}$}} \\
\hline & & & \\
\hline & & \multicolumn{2}{|c|}{ 熱抵抗：0.011( $\left.\mathrm{m}^{2} \cdot \mathrm{K}\right) / \mathrm{W}$} \\
\hline 窓方位 & \multicolumn{3}{|r|}{ 真南 } \\
\hline \multirow{4}{*}{ 空ガラス } & \multicolumn{3}{|c|}{$6.1 \mathrm{~m}^{2}$ (空面積/床面積：38.6\%) } \\
\hline & \multicolumn{3}{|c|}{ WFL5-Ar12-WFL5, U值 $=2.9 \mathrm{~W} /\left(\mathrm{m}^{2} \cdot \mathrm{K}\right)$} \\
\hline & \multicolumn{3}{|c|}{ 高透過複層ガラス (Arガス入り) } \\
\hline & \multicolumn{3}{|c|}{ 日射透過率：0.81，日射熱取得率： 0.84} \\
\hline 実験期間 & \multicolumn{3}{|c|}{ 2012年12月～2013年2月 } \\
\hline \multicolumn{4}{|c|}{ 表 4 外皮層構成 } \\
\hline \multirow{7}{*}{$\begin{array}{c}\text { 天井 } \\
\text { (外部より) }\end{array}$} & \multicolumn{2}{|c|}{ 鋼板 } & $\mathrm{t}=0.5 \mathrm{~mm}$ \\
\hline & \multicolumn{2}{|c|}{ 構造用合板 } & $\mathrm{t}=24 \mathrm{~mm}$ \\
\hline & 空気 & & \\
\hline & 発泡木 & リエチレンフォーム3種 & $\mathrm{t}=75 \mathrm{~mm}$ \\
\hline & 合板 & & $\mathrm{t}=5.5 \mathrm{~mm}$ \\
\hline & PCM & & $\mathrm{t}=10 \mathrm{~mm}$ \\
\hline & 繊維弓 & 化セメント板 & $\mathrm{t}=4.0 \mathrm{~mm}$ \\
\hline & 鋼板 & & $\mathrm{t}=0.5 \mathrm{~mm}$ \\
\hline & 発泡木 & リエチレンフォーム3種 & $\mathrm{t}=30 \mathrm{~mm}$ \\
\hline & 合板 & & $\mathrm{t}=12 \mathrm{~mm}$ \\
\hline (外部より) & 発泡才 & リエチレンフォーム3種 & $\mathrm{t}=45 \mathrm{~mm}$ \\
\hline & 合板 & & $\mathrm{t}=12 \mathrm{~mm}$ \\
\hline & PCM & & $\mathrm{t}=10 \mathrm{~mm}$ \\
\hline & 織維弓 & 化セメント板 & $\mathrm{t}=4.0 \mathrm{~mm}$ \\
\hline & 発泡木 & リエチレンフォーム3種 & $\mathrm{t}=225 \mathrm{~mm}$ \\
\hline & 構造月 & 合板 & $\mathrm{t}=24 \mathrm{~mm}$ \\
\hline & 発泡才 & リエチレンフォーム3種 & $\mathrm{t}=45 \mathrm{~mm}$ \\
\hline (外部より) & PCM & & $\mathrm{t}=10 \mathrm{~mm}$ \\
\hline & 鋼板 & & $\mathrm{t}=2.4 \mathrm{~mm}$ \\
\hline & 高伝i & フローリング & $\mathrm{t}=3.5 \mathrm{~mm}$ \\
\hline
\end{tabular}
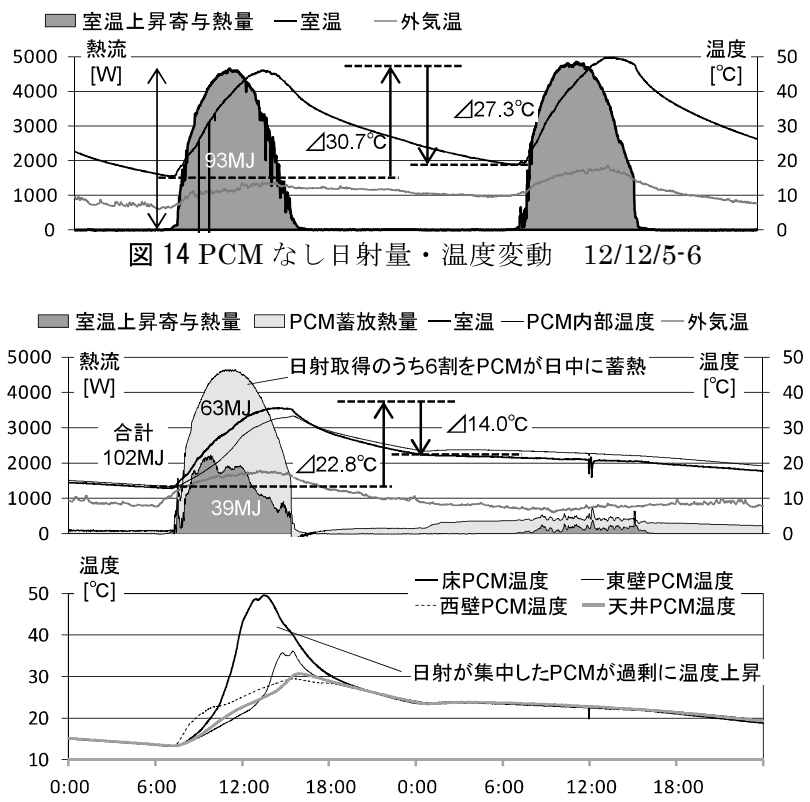

図 15 PCM あり日射量・温度変動 $12 / 12 / 16-17$

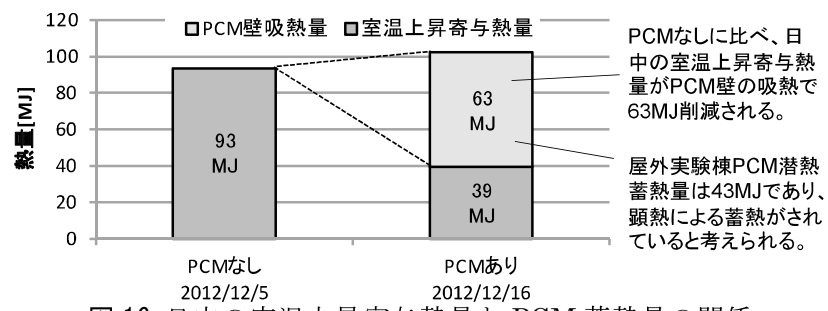

図 16 日中の室温上昇寄与熱量と PCM 蓄熱量の関係

より最高気温に至る温度上昇幅が $7.9^{\circ} \mathrm{C}$ 低減し, 夜間の放熱により 翌朝日の出の時刻に至る温度下降幅が $13.3^{\circ} \mathrm{C}$ 低減した. また, $\mathrm{PCM}$ を敷設した場合は，快晴日の翌日の日射熱取得が少量でも，快晴日 の日没から翌日の日没までの 24.8 時間, 室温が $20^{\circ} \mathrm{C}$ 以下とならな いことが確認できた。しかし，空を透過した日射熱が床に集中寸る ことが原因で, 床に敷設された PCM の内部温度が午前 11 時に相変 化温度帯を超え, その後 $50^{\circ} \mathrm{C}$ まで達している。このことから, 床面 等，入射日射が集中する部位の PCM 敷設量を増加させることで， 恒温性が向上すると考えられる。

図 16 に各条件において，室内に入射した日射量のうちで室温上 昇に寄与した熱量と PCM に吸収された熱量のグラフを示寸。室温 上昇寄与熱量は空面透過日射量から PCM の吸熱量注5)を引いた值 として算出している.PCM 敷設ありなしの比較では, PCM ありの 場合に空面透過日射量のうち $63 \mathrm{MJ}$ が吸熱され，室温上昇寄与熱量 が 39MJ と PCM なしの場合に比べて低減された。また室に敷設し た PCM の合計の潜熱蓄熱量が $43 \mathrm{MJ}$ であることから，顕熱による 蓄熱がなされ壁表面温度が上昇したために，PCM による恒温性が 低減したと考えられる，以上のことから，室全体に PCM を配した 際に恒温性が高まることが確認された。

\section{3 検討 3 : 熱回路網計算を用いた P C M 室内導入手法の検証}

屋外実験装置における実測では検証パターンが限られるため, 非 定常 1 次元熱回路網計算プログラム 10)を用い, 屋外実験装置の熱回 路網計算モデルを作成した。モデルの仕様を図 17 に, 計算条件を 表 5 に示す。外皮のモデルは表 3,4 に準じた。屋外実験装置の空前 


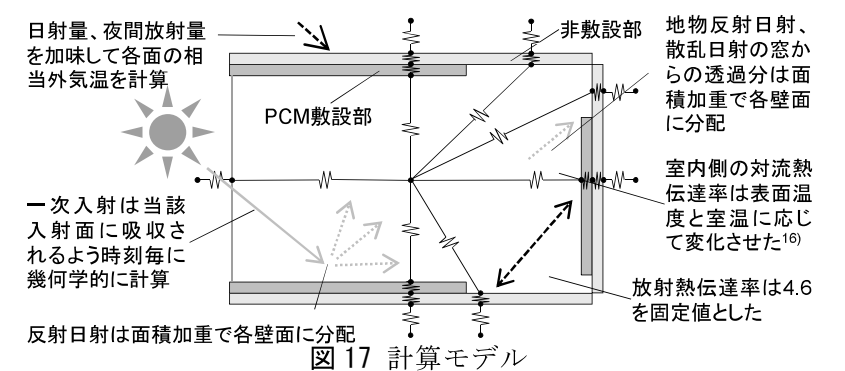

表 5 計算条件

\begin{tabular}{|c|c|c|c|}
\hline 計算方法 & 非定常1次元熱伝達 & 計算時間間隔 & 10 分 \\
\hline \multirow{2}{*}{ 気象条件 } & 拡張アメダス(東京都/東京地点) & \multirow{2}{*}{ 換気回数 } & 0.5 回 $/ \mathrm{h}$ \\
& 実測值(精度検証時) & & 0 回 $/ \mathrm{h}$ (精度検証時) \\
\hline
\end{tabular}

$$
\begin{aligned}
& \begin{array}{l}
\text { 顕熱比熱式 } \\
\text { 比熱式(蓄熱) }
\end{array} \quad C_{p \text { const }}=\left\{\begin{array}{c}
1.9(T<0), 2.6(T>40) \\
1.9+0.0175 T(0 \leq T \leq 40)
\end{array}\right.
\end{aligned}
$$

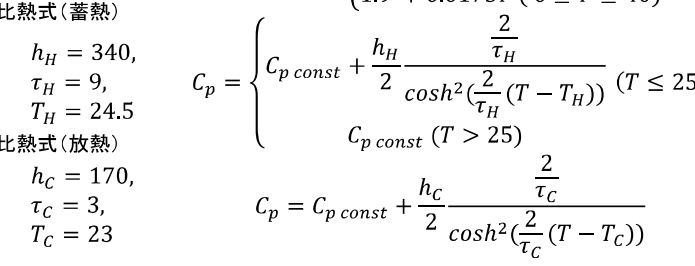

$T:$ PCM現在温度 $[K], C_{p}$ : 比熱 $[\mathrm{kJ} / \mathrm{kg} \cdot \mathrm{K}], h_{H}, h_{C}$ : 潜熱量 $[\mathrm{kJ} / \mathrm{kg} \cdot \mathrm{K}]$ $\tau_{H}, \tau_{C}:$ 相変化温度幅 $[K], T_{H}, T_{C}$ : 比熱 ※添字のH,Cは蓄熱、放熱過程を意味する

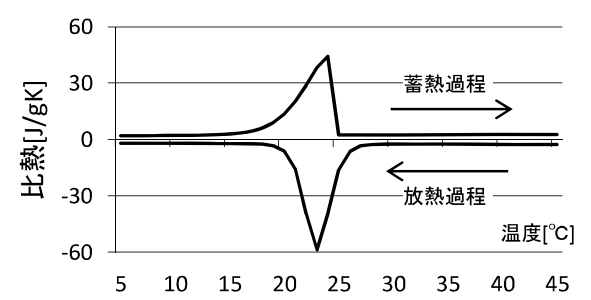

図 18 蓄放熱過程の近似比熱曲線

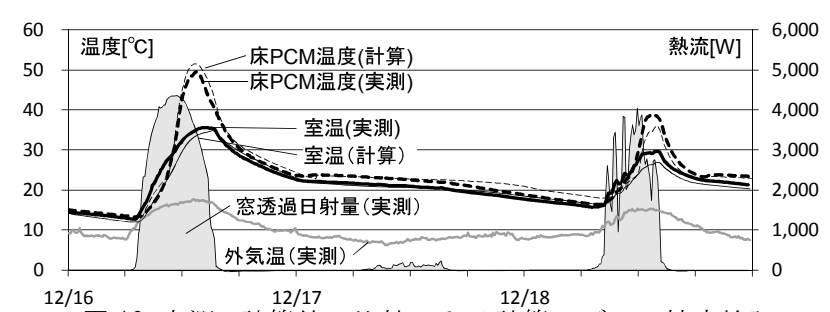

図 19 実測・計算值の比較による計算モデルの精度検証

面地面が建物の屋上面であることを反映させるため, アルベドにつ いては既往研究 11)の実験式を用いたＰCM の蓄放熱を再現するに は, 固液相の状態量により変化する PCM の見かけの比熱が必要に なる.ここでは, 温度の関数で表される Feustel ${ }^{12)} の$ 式を用い, 物 性值に基づき(1)〜(3)式で比熱曲線を近似した。

比熱の近似曲線は図 18 に示した通りである. 蓄熱放熱過程の比 熱式の入れ替えは相良, 山中ら 13)の過冷却を考慮するアルゴリズム を用いた。 図 19 に計算値と実測値の比較を示寸. 日射量, 気温変 動の異なる 3 日間において室温, 床面 PCM 温度ともに計算值と実 測値が精度良く一致することが確認された。

次に，拡張アメダス気象データ 14（東京都東京地点標準年）を用 いて冬期の $12 / 1$ から $3 / 31$ までの期間でシミュレーションを行った. $\mathrm{PCM}$ の蓄放熱性能に与える影響の検証として，蓄放熱面積につい ては 0.5 倍と 1.5 倍と, $\mathrm{PCM}$ の蓄熱量については 0.5 倍と 2 倍と変 えて, 計算した結果を代表日について図 20,21に示す。蓄放熱面積 では室温平準化効果に大きな差が見られないこと, 蓄熱量では増加
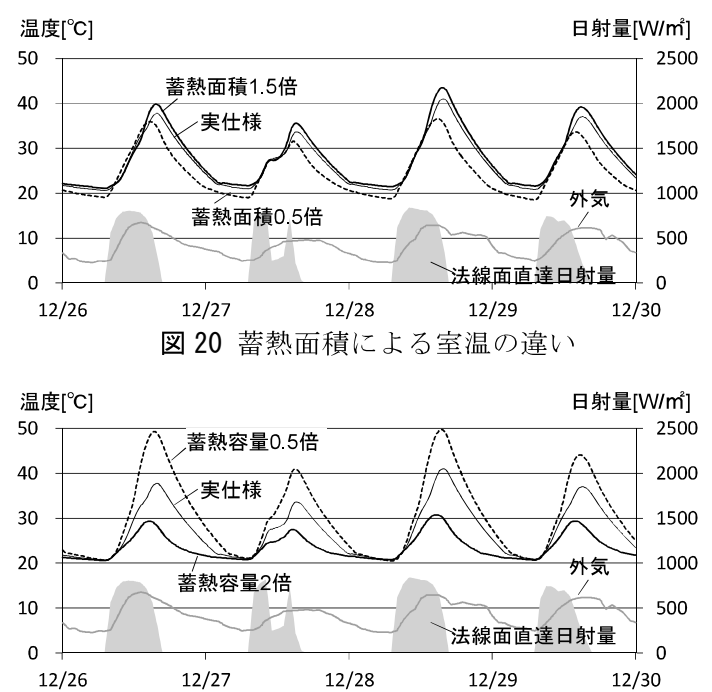

図 21 蓄熱面積と蓄熱容量による室温の違い

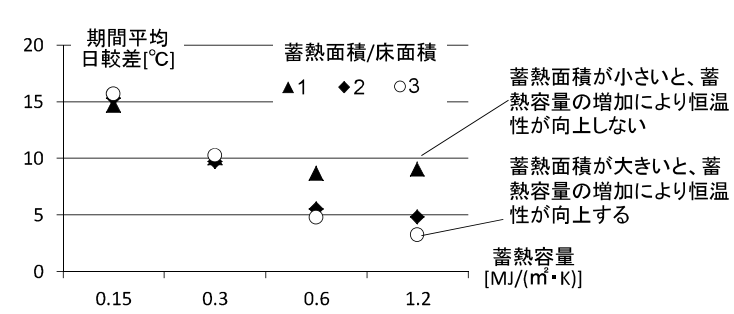

図 22 蓄熱面積と蓄熱容量による日較差の違い

することによる恒温性の向上が認められた．

次に, 敷設面積・量による恒温性の把握を行うため, 敷設面積/床 面積(以降, 蓄熱面積) 3 種 $(1,2,3)$ と蓄熱量/床面積(以降, 蓄熱容量) の 4 種 $\left(0.15,0.3,0.6,1.2 \mathrm{MJ} /\left(\mathrm{m}^{2} \cdot \mathrm{K}\right)\right)$ の計 12 ケースで計算した. 日較差の違いを図 22 に示す．蓄熱容量が大きいと蓄熱面積が大き い場合の恒温性を向上させる効果が大きく, 屋外実験装置の仕様 $\left(0.29 \mathrm{MJ} /\left(\mathrm{m}^{2} \cdot \mathrm{K}\right)\right.$, 蓄熱面積/床面積 1.99$)$ では蓄熱面積の違いで日較 差が変わらないこと, 蓄熱量を 2 倍にして日較差が半減することが わかった。屋外実験装置の断熱性能・空面積と蓄熱性能のバランス の考察は次章の課題とした.

\section{3．ダイレクトゲインを用いた太陽熱暖房住宅の評価法}

\section{1 設計指針の整理とデータベースの作成}

以上の実験から, $10 \mathrm{~mm}$ 程度の厚さの PCM の敷設と DG だけで, 十分に快適性の高い環境の住宅が設計できる可能性が示された。し かし屋外実験装置においては，PCM の潜熱蓄熱量に対して空から の日射熱取得量が多く, 室温は昼間に約 $35^{\circ} \mathrm{C}$ まで上昇しオーバーヒ 一トしている。このように実物件に PCM を導入し，空からの日射 熱取得のみで安定した室温変動を得るためには, 躯体の断熱性能, 空からの日射熱取得性能, 蓄熱容量, 蓄熱面積の, 計 4 点のバラン スを取るための設計指針が必要とされている.

以上の 4 点を設計する際, まずは躯体の断熱性能を確保した上で, 空からの適切な日射熱取得を行うべきである，そこで，木造 2 階建 ての住宅への蓄熱体の導入を前提とし, 前章で精度が検証された PCM モデルと図 23，表 6 に示寸計算モデルを用い，拡張アメダス データ(東京都東京地点標準年)の冬期（12/1 から 3/31）において, 蓄熱体を導入しないケースとして, 南空面積/延床面積(以降, 南空/ 


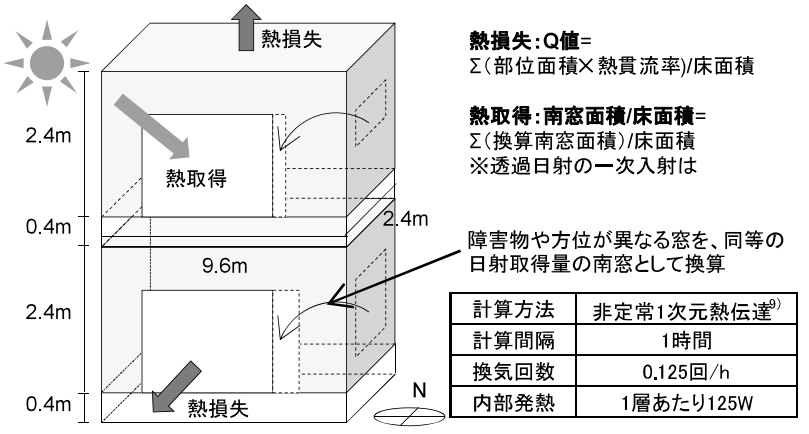

図 23 モデル建物注 6)

表 6 モデル建物外皮層構成

\begin{tabular}{|c|c|c|}
\hline \multirow{5}{*}{$\begin{array}{c}\text { 天井 } \\
\text { (外部より) }\end{array}$} & スレート & $t=4 \mathrm{~mm}$ \\
\hline & 合板 & $t=12 \mathrm{~mm}$ \\
\hline & \multicolumn{2}{|c|}{ 硬質ウレタンフォーム 厚みはQ值により調整 } \\
\hline & 石高ボード & $t=12 \mathrm{~mm}$ \\
\hline & 合板 & $\mathrm{t}=5.5 \mathrm{~mm}$ \\
\hline \multirow{5}{*}{ (外部より) } & サイディング & $t=15 \mathrm{~mm}$ \\
\hline & 通気層 & \\
\hline & \multicolumn{2}{|c|}{ 硬質ウレタンフォーム 厚みはQ值により調整 } \\
\hline & \multicolumn{2}{|c|}{ 土壁。rPCM 厚みは熱容量により調整 } \\
\hline & \multicolumn{2}{|l|}{ 石育ボード } \\
\hline \multirow{4}{*}{$\begin{array}{c}\text { 床面 } \\
\text { (外部より) }\end{array}$} & \multicolumn{2}{|c|}{ 硬質ウレタンフォーム＼cjkstart厚みはQ值により調寈 } \\
\hline & 合板 & $t=12 \mathrm{~mm}$ \\
\hline & \multicolumn{2}{|c|}{ 土壁orPCM 厚みは熱容量により調整 } \\
\hline & フローリング & $t=12 \mathrm{~mm}$ \\
\hline \multirow{3}{*}{ 悹 } & \multicolumn{2}{|c|}{ 日射透過率: 0.74} \\
\hline & \multicolumn{2}{|c|}{ 日射熱取得率: 0.79} \\
\hline & \multicolumn{2}{|c|}{ 熱貫 } \\
\hline
\end{tabular}

※PCM 非敷設部には網掛部は省略する

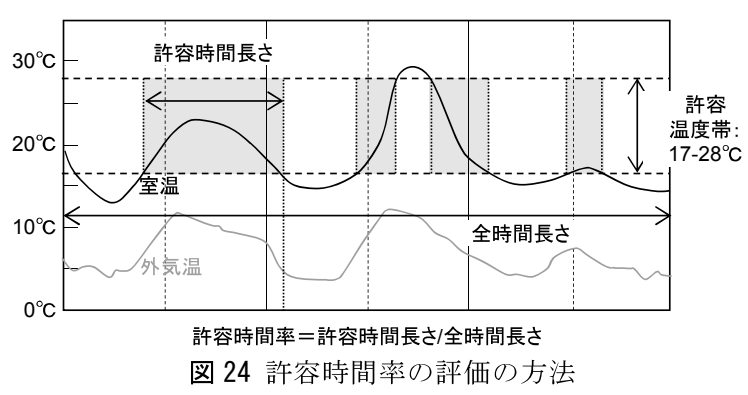

床)を 5 から $60 \%$ の 10 種 $(5,7.5,10,12.5,15,20,30,40,50,60)$ ， $\mathrm{Q}$ 值は 0.5 から $5.0 \mathrm{~W} /\left(\mathrm{m}^{2} \cdot \mathrm{K}\right)$ の 10 種 $(0.5,0.75,1.0,1.25,1.5,2.0$, $2.5,3.0,4.0,5.0)$ の組み合わせによる, 計 100 ケースの自然室温計 算を行った。 各ケースの温熱環境を評価する指標として, 計算期間 の自然室温が $17 \sim 28^{\circ} \mathrm{C}$ の範囲の時間長さを全時間長さで除した許 容時間率（図 24）注7) を用いることとした. 本研究で対象とした住 宅において, 建築プログラムの特性上から厳密な温度制御が必ずし も必要とされるわけではなく, 太陽熱を最大限に活用寸るためには 居住者が多少の室温変動であれば許容して着衣量等を調整しながら 生活するといったことも考えられる. そこで今回はなる心゙く太陽エ ネルギーに依存した, 補助暖房設備に頼らない住宅の基本設計（建 物ボリューム・断熱性能・開口面積・蓄熱性能）を評価するために, 暖房負荷による検討を初期段階から行うのではなく, 無暖房条件下 の自然室温を数值計算によって求めた結果から得られる許容時間率 を評価指標とすることを提案する。注8)

計算結果について, 横軸に $\mathrm{Q}$ 值, 縦軸に南空/床をとった許容時 間率の等高線図を作成した (図 25 , 以降, 許容線図)。Q 值が 4.0
から $5.0 \mathrm{~W} /\left(\mathrm{m}^{2} \cdot \mathrm{K}\right)$ で断熱性能が不足しており, 南空/床が $10 \%$ 以下 の日射熱取得が少ないケースにおいて許容時間率が $10 \%$ 以下と低 いこと, 一方で $\mathrm{Q}$ 值が 0.5 から 1.0 で断熱性能が高く, 南空/床が $40 \%$ 以上で日射熱取得が多いケースにおいても，許容時間率が $10 \%$ 以下と低いことがわかる。高温の時間帯が少なく, 許容時間率 80,90\%以上のケースは図中の白円で囲った狭い範囲に限られる. 次 に, PCM を導入した場合を考慮するため, 蓄熱面積 3 種, 蓄熱容 量 2 種の合計 6 種の蓄熱条件 1 つにつき, 100 ケースの計算を同様 に行った（図 26）。蓄熱容量・蓄熱面積ともに大きいと許容時間率 が高いケースが増加することがわかる，蓄熱容量が多い場合，蓄熱 面積を広げる程, 許容時間率が高まるケースが増える一方で, 蓄熱 容量が少ない場合は, 蓄熱面積が小さくても十分な蓄放熱が行える ため，蓄熱面積による違いが出ないことが明らかになった。

\section{2 許容線図の応用とダイレクトゲインを用いた太陽熱暖房住 宅の評価法の提案}

前項で作成した許容線図で屋外実験装置の位置づけを分析するた めには, 屋外実験装置の $\mathrm{Q}$ 值, 南空/床の値を算出する必要がある. 計算モデルにおいては障害物のない, 日射熱取得率 0.79 の複層ガラ

$$
A_{\text {swin }}=\sum_{i=1}^{n} A_{\text {win }_{i}} \cdot P_{\text {Swin }_{i}} \cdot \frac{\eta_{i}}{\eta_{0}}
$$

$A_{s w i n}:$ 南空面積/延床面積, $A_{w i n_{i}}:$ 各空面積/延床面積,

$P_{\text {Swin }}$ : 各悹南空換算率, $\eta_{i}$ : 各空日射熱取得率, $\eta_{0}$ : モデル空日射熱取得率

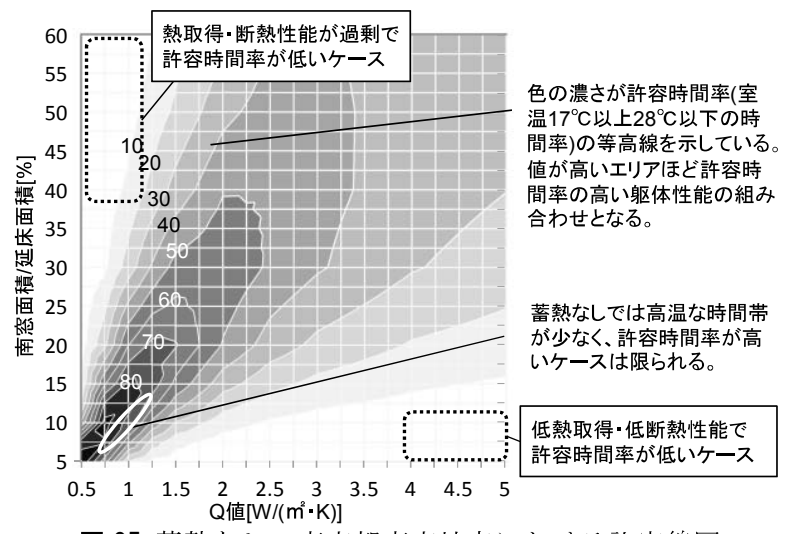

図 25 蓄熱なし・東京都東京地点における許容線図

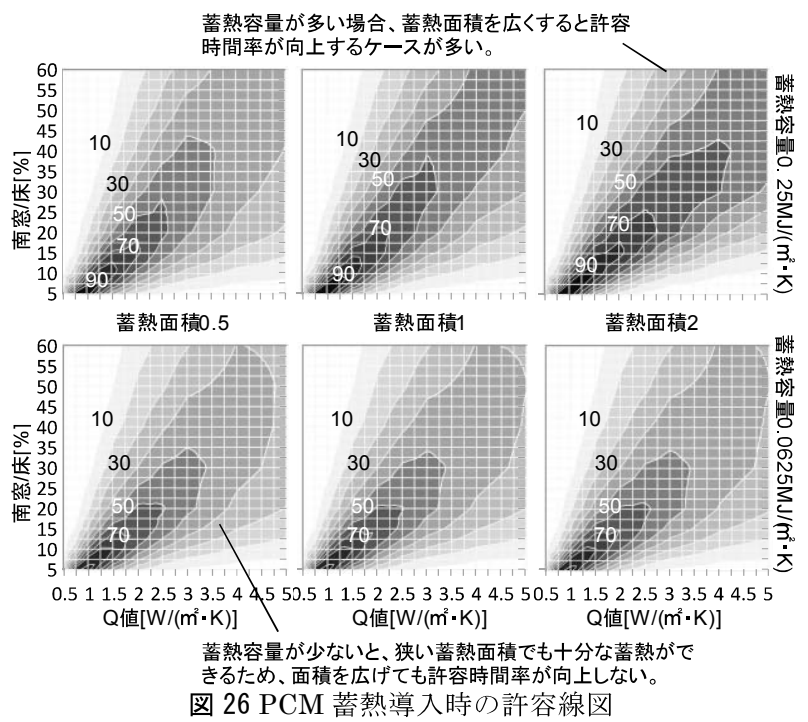


スの南面空を用いているため, 式(4)を用い屋外実験装置の南空/床 である $A_{\text {swin }}$ を算出することとした。注9)

式(4)中の各空南空換算率は, 障害物のない南面空と異なる日射熱 取得条件にある空の，冬期(12/1 から 3/31)における積算全天入射日 射量について，後者を前者で除した值である. 図 27,28 では建物の 方位角の絶対值と, 隣棟障害物, 庇の $\mathrm{D} / \mathrm{H}$ にって変わる南空換算 率を算出した。 これを用い, 複数方位の空や日射熱取得率, 屋外障 害物の影響を加味した合計の日射熱取得性能を, 障害物のない複層 ガラスの南面空面積に補正を行った。

次に Q 值の計算式は汎用式 15)を用いているが，それを展開し，許 容線図の縦横軸に合わせて展開寸る注10) と式(5)となる.

$A_{\text {swin }}=P_{\text {swin }} \cdot \frac{Q-\left\{\left(A_{W}+A_{\text {win }}\right) \cdot U_{W}+A_{R} \cdot U_{R}+A_{F} \cdot U_{F}\right\}-V}{U_{w i n-} U_{W}}$

$Q: Q$ 値 $\left[\mathrm{W} /\left(\mathrm{m}^{2} \cdot \mathrm{K}\right)\right], A_{W}$ : 壁面積/延床面積, $A_{R}$ : 屋根面積/延床面積, $A_{F}:$ 床面積/延床面積, $A_{w i n}:$ 空面積/延床面積, $A_{s w i n}:$ 南空面積/延床面積, $U_{W}$ : 壁熱貫流率 $\left[\mathrm{W} /\left(\mathrm{m}^{2} \cdot \mathrm{K}\right)\right], U_{R}$ : 屋根熱貫流率 $\left[\mathrm{W} /\left(\mathrm{m}^{2} \cdot \mathrm{K}\right)\right], U_{F}$ : 床熱貫流率 $\left[\mathrm{W} /\left(\mathrm{m}^{2} \cdot \mathrm{K}\right)\right]$ $U_{w i n}$ : 空熱貫流率 $\left[\mathrm{W} /\left(\mathrm{m}^{2} \cdot \mathrm{K}\right)\right], V:$ 換気負荷 $\left[\mathrm{W} /\left(\mathrm{m}^{2} \cdot \mathrm{K}\right)\right], P_{\text {swin }}$ : 全体南空換算率

表 3 をふまえ, 屋外実験装置と同等の蓄熱量・面積である許容線 図に，表 3，4 と式(5)を用いて躯体性能をプロットした（図 29）. 式(5)をプロットした図中の直線 1 が示すのは, 躯体の部位性能・建 物全体の形状と敷地条件が変わらない条件で, 空面積のみを拡大縮 小した時に，その物件がとり得る許容時間率の範囲である．現状の

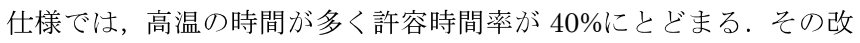
善案 1 として, 躯体性能・敷地条件をそのままに, 南空/床を $12 \%$ に落とすと高温な時間帯が減少し, 許容時間率が $90 \%$ に向上するこ とがわかる.また，改善案 2 として主開口の正対する方位を南東一 $45^{\circ}$ ずらした場合でも同様にプロット（図中直線 2 ) を行うと, 高 温の時間が短くなり, 許容時間率が $80 \%$ に向上寸る. 以上のように, 屋外実験装置を例として, 躯体の断熱性能，空からの日射熱取得性 能, 蓄熱量, 蓄熱面積の, 計 4 点のバランスを取るための設計評価 が可能となる.

ここで述べた手法は DGを用いた太陽熱暖房住宅の評価法として 活用ができる．設計要素を前節に即して整理すると，図 30 のよう になる。このうちの気象条件については, 各地域の同じ期間の気象 データに対して同様に許容線図を描くことができる(図 31). 計算は 冬期の日射量と平均気温別を考慮し選定した 10 地点で行い, その うち旭川・山形・東京・宮崎の気象データを用いて計算した結果を 示寸.許容時間率の高い躯体性能の組合せが, 日射量が小さい旭川, 山形では限られているが，日射量が大きく温暖な東京・宮崎ではよ り多くの $\mathrm{Q}$ 值と南空/床の組み合わせが許容されることがわかる. つまり，この線図を用いればどの地域でどのような躯体性能にすれ ば, 許容時間率の高い DG を用いた太陽熱暖房住宅の設計が可能か を把握できる. また, 許容線図は複数の国・地域の省エネルギー住 宅の躯体性能基準の分析にも用いることができる，ここでは，世界 各国の住宅の省エネルギー基準值注 1 1) と標準住宅 16 )の躯体形状を 用い，冬期に同等の平均気温を持つ各地域の線図上にプロットを行 った.この時, 直線が許容時間率の高い領域をより多く通る場合は, 断熱規定がその気候に適合していると判断できる. 寒冷地において はドイツの基準，温暖地においてはカリフォルニアの基準が該当す る一方, 日本は空の断熱基準值が低く，建物形状の工夫のみによる

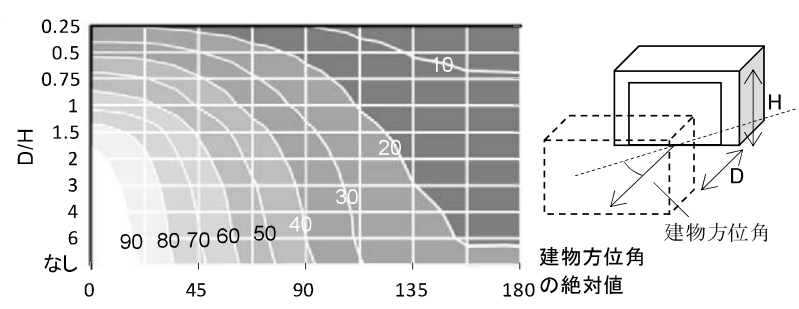

図 27 拡張アメダス東京における障害物距離空面方位別南空換算率

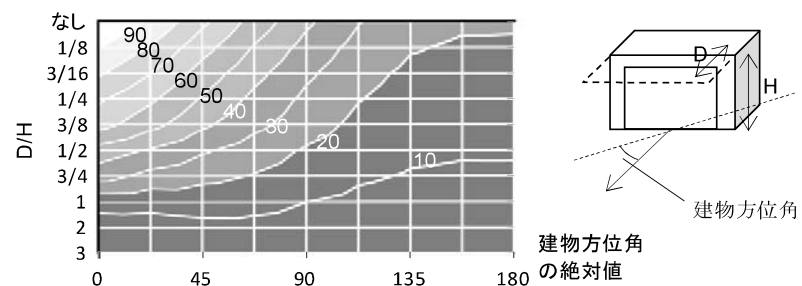

図 28 拡張アメダス東京における庇長さ空面方位別南空換算率

拡張アメダス東京: PCM 蓄熱面積 2 容量 $0.25\left[\mathrm{MJ} /\left(\mathrm{m}^{2} \cdot \mathrm{K}\right)\right]$

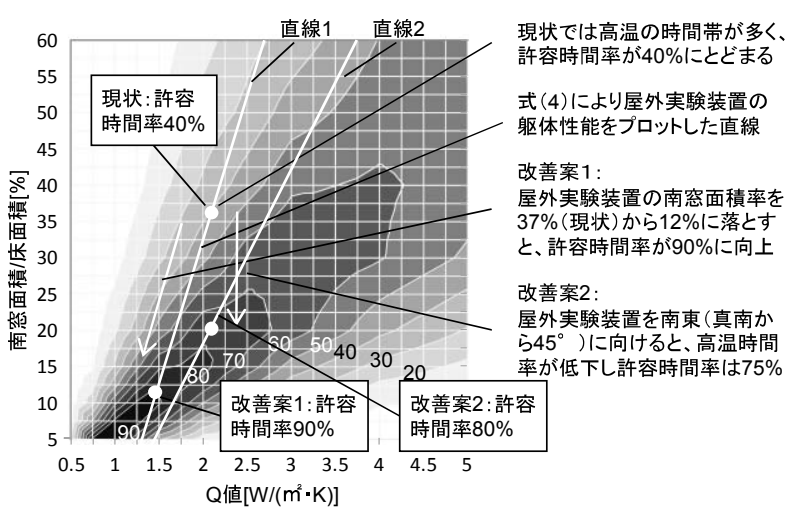

図 29 許容線図による屋上実験装置の分析

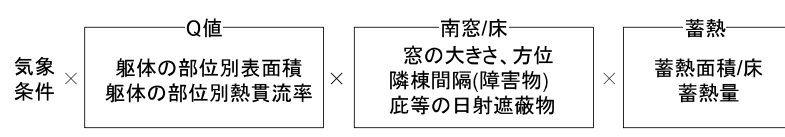

図 $30 \mathrm{DG}$ を用いた太陽熱暖房住宅の設計要素の整理

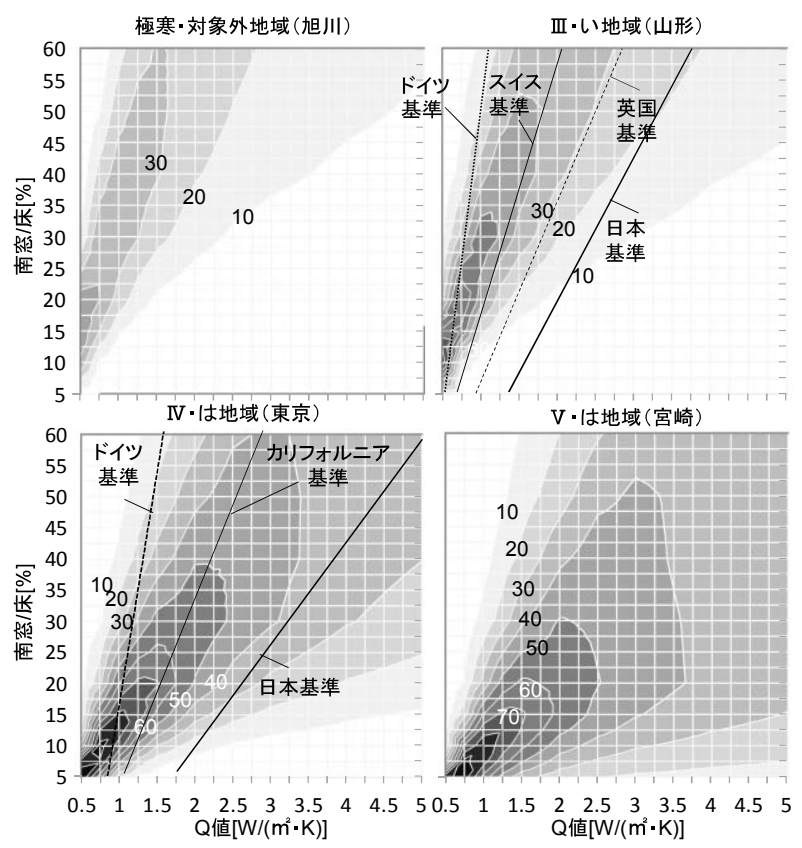

図 31 地域別の許容線図と各国・地域の基準 


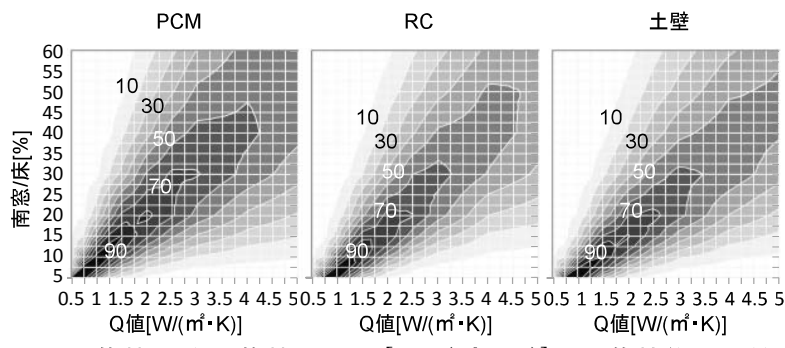

図 32 蓄熱面積 2 , 蓄熱量 $0.25\left[\mathrm{MJ} /\left(\mathrm{m}^{2} \cdot \mathrm{K}\right)\right]$ での蓄熱体の比較 気象条件：拡張アメダスデータ東京都東京地点(標準年)

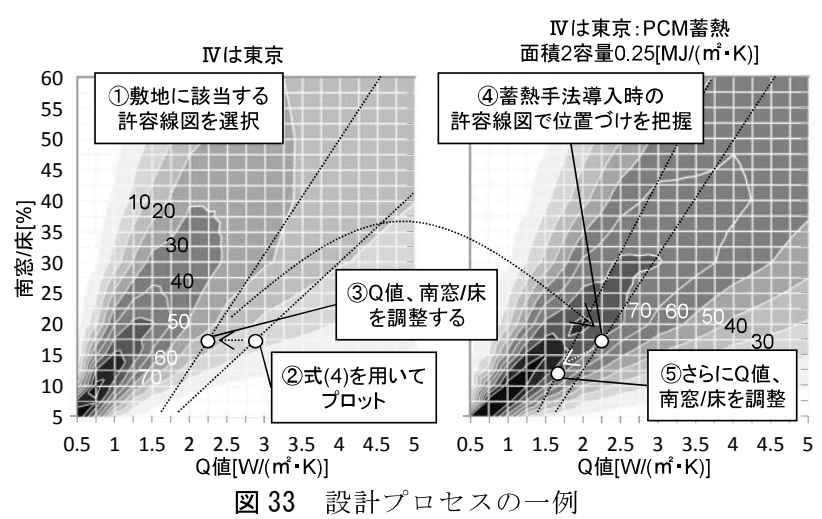

許容時間率の向上が多くの地域で見込めないことがわかる.

蓄熱体の性質の違いについても許容線図を用いて考察することが

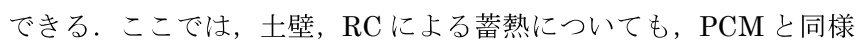
の計算を行った、結果の一部を図 32 に示寸. 同等の熱取得, 南空/ 床のバランス, 同等の蓄熱面積, 蓄熱容量であっても, PCM 導入 の場合は土壁・ RC に比べ許容時間率が高い.これは土壁・ RC と同 等の蓄放熱量であっても, PCM を敷設したことで, 室温と共に許 容温度帯で安定する時間が長くなるためである. 結果として, 許容 時間率の高い躯体性能の組合せが多くなり, PCM はダイレクトゲ インを用いた太陽熱暖房住宅の, 躯体性能の設計の自由度を広げる ものとして期待できることが明らかとなった。

これまでで説明した線図を用いれば，以下のような手順での太陽 熱暖房住宅の設計プロセスの提案も可能である. (1)敷地に該当する 気象条件で計算した許容線図を用意する. (2)設計対象住宅のプラン や断熱仕様等が決まった段階で, Q 值と南空/床を計算し, 許容線図 上に式(4)を用いてプロットし許容時間率を把握する。 (3)許容時間率 を高めるように, 建物形状や躯体性能の調整を行う。(4)蓄熱を利用 する場合は，該当寸る気象・蓄熱条件で計算された線図を用意し再 度プロット寸る. (5)許容時間率の把握と建物形状や身区体性能の調整 を行うという手順となる。例として, 東京で PCM を用い蓄熱面積 2 , 蓄熱量 $0.25 \mathrm{MJ} /\left(\mathrm{m}^{2} \cdot \mathrm{K}\right)$ の $\mathrm{DG}$ を用いた太陽熱暖房住宅が設計さ れるまでのプロセスを図 33 に示した.

\section{4 まとめ}

これまでの検討から,以下の結論及び課題を挙げることができる

1）熱箱と人工太陽を用いた実験により, 熱伝導率, 日射吸収率の 異なる仕上げ材共通で, PCM3 面敷設は 1 面敷設と比較して箱 内最高温度が $1.2 \sim 1.7^{\circ} \mathrm{C}$ 低減され, 非照射 4 時間後の箱内温度 が $1 \sim 1.5^{\circ} \mathrm{C}$ 上昇した.
2）屋外実験装置を用いて実気象条件下で PCM の恒温性を確認で きた。 PCM を敷設した場合は快晴の日の翌日の日射量が少な くても, 前日の日没からその日の日没までの 24.8 時間, 室温 が $20^{\circ} \mathrm{C}$ 以下とならないことを確認した。

3）特定の気象条件下で実現する住宅の自然室温を許容時間率で 評価することで，太陽熱を最大限利用し得る建物の断熱・日射 熱取得・蓄熱性能を検証する，DG と躯体蓄熱を用いた太陽熱 暖房住宅の評価法を提案した.

4）東京の気象条件下で PCM を蓄熱体として用いる場合は，蓄熱 容量 $0.25 \mathrm{MJ} /\left(\mathrm{m}^{2} \cdot \mathrm{K}\right)$ と多い場合, 敷設面積を広げる程恒温性 の向上が見込める。一方，蓄熱容量 $0.0625 \mathrm{MJ} /\left(\mathrm{m}^{2} \cdot \mathrm{K}\right)$ と少な い場合, 敷設面積が小さくても十分な蓄放熱が行え, 敷設面積 による許容時間率の違いがないことが，3)に記した線図を用い て把握された。

5）屋外実験装置では, 南空の大きさを現状に比べて 6 割小さくす ることによって許容時間率が $90 \%$ 以上になることが 3 )に記し た線図を用いて把握することができた.

6）本研究が提案する評価法は，ダイレクトゲインを用いた太陽熱 暖房住宅における, 室内外の熱の授受と蓄熱体内外の熱の授受 に影響を与える要素として，躯体の断熱性能，空からの日射熱 取得性能, 蓄熱体の量と敷設面積を取り上げ，特定の気象条件 下で住宅全体の許容時間率が高い組合せを検討するものであ る. 住宅内部の間仕切り位置や室のプロポーション等, 居住性 に影響を与えるより詳細な要素の検討については今後の課題 である。

7）本研究では冬期における太陽熱暖房住宅の快適性の向上を目 指した評価法を提案したが，夏期においてはダイレクトゲイン のための空が冷房負荷の増加をもたらす可能性が高く, すだれ や外ブラインド等での日射遮蔽が肝要である.

\section{謝辞}

本研究は, 科学研究費助成事業・基盤（B）「空や日射制御・潜熱蓄 熱を最適化した低コストで快適性の高い太陽熱暖房の開発」(H24 $\sim 26$ 年度, 研究代表者: 前真之) の研究成果による. 多大なるご 支援を頂いた井上隆教授, 同研究室 (東京理科大学)，一八瀬雅之准 教授（首都大学東京），木下泰斗氏（日本板硝子株式会社）に感謝の 意を表す.

注

注1）本論で用いる地域区分は全て，平成 11 年度省エネルギー基準によるも のとした.

注2）人工太陽光源は $2 \mathrm{~kW}$ のメタルハライドランプを用い，自然太陽光との 波長合致度は JIS 8912 に㧍ける等級 B，照射ムラが土10\%以内となる 有効照射面積は $300 \mathrm{~mm}$ 角, 放射照度の最大出力は $1 \mathrm{~kW} / \mathrm{m}^{2}$ である。

注3）本来は太陽高度を考慮した照射をすべきだが, 本実験で用いた 1 灯式の 人工太陽光源は距離による減衰が大きく，角度をつけた照射を行うと， 各受照面に扔ける入射日射量に大きな差がつくと予想された。そんのため, 水平照射した人工太陽光をすりガラスによって拡散し，できるだけ模型 箱の各受照面における入射日射量のむらを無くすことにより，敷設面積 や仕上げ材により異なる $\mathrm{PCM}$ の蓄放熱性状を比較することとした。

注4）潜熱量を $\left[\mathrm{W} / \mathrm{m}^{2} \cdot \mathrm{K}\right]$ で表記する際は, 本研究で許容範囲と定めた $17-28^{\circ} \mathrm{C}$ の間の顕熱量と潜熱量を足しあわせた值を, $11^{\circ} \mathrm{C}$ の温度幅で除すことに よって求めた。 
注5）計測点概要は補図 1 の通りである. 垂直温度測定点は床から 0 (床表 面), $50,100,500,750,1100,1500,1800,2250$ (天井表面） $\mathrm{mm}$ の高さで訃 測を行い， $750 \mathrm{~mm}$ の高さのみグローブ温度もあわせて設置している. 表面温度測定点では, 仕上げ材表面, PCM 室内側, 室外側表面温度を 測定している．室温は $750 \mathrm{~mm}$ の高さの温度測定点の平均値を用い, PCM 温度は PCM 室内外表面温度を面積加重で按分して算出した. PCM 吸放熱量は各熱流計測定值に, 代表できる部分の PCM 敷設面積 を乗じて算出した. 垂直面空面透過日射計測定値に空面積を乗じること によって空面透過日射量を算出した。

注6）計算モデルにおいて内部発熱を一層につき $125 \mathrm{~W}$ としたのは, 一般の住

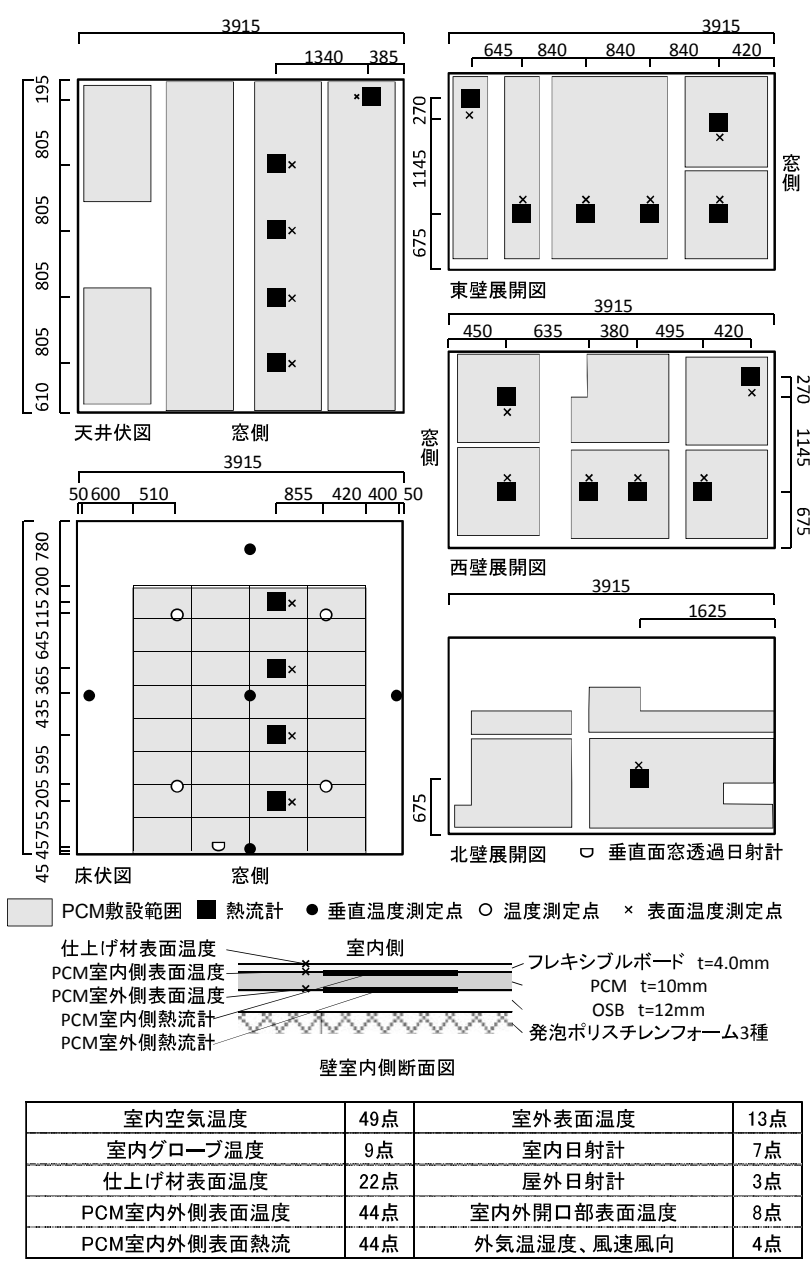

補図 1 屋外実験装置計測点概要

$$
\begin{aligned}
Q & =A_{W} \cdot U_{W}+A_{R} \cdot U_{R}+A_{F} \cdot U_{F}+A_{w i n} \cdot U_{w i n}-V \\
& =\left(A_{W}+A_{w i n}\right) \cdot U_{W}+A_{R} \cdot U_{R}+A_{F} \cdot U_{F}+A_{\text {win }} \cdot\left(U_{w i n}-U_{W}\right)-V \\
& =\left(A_{W}+A_{w i n}\right) \cdot U_{W}+A_{R} \cdot U_{R}+A_{F} \cdot U_{F}+\frac{A_{\text {swin }}}{P_{\text {swin }}} \cdot\left(U_{w i n}-U_{W}\right)-V
\end{aligned}
$$

補表 1 参照した省エネルギー基準

\begin{tabular}{|c|c|}
\hline 日本 & 省エネルギー基準(1999) \\
\hline ドイツ & Passivhaus基集(2007) \\
\hline スイス & Minergiere基準(2008) \\
\hline 米国カルフオルニア & Building Energy Efficiency Standards(2008) \\
\hline 英国 & Energy Efficiency Requirements for New Dwellings(2010) \\
\hline
\end{tabular}

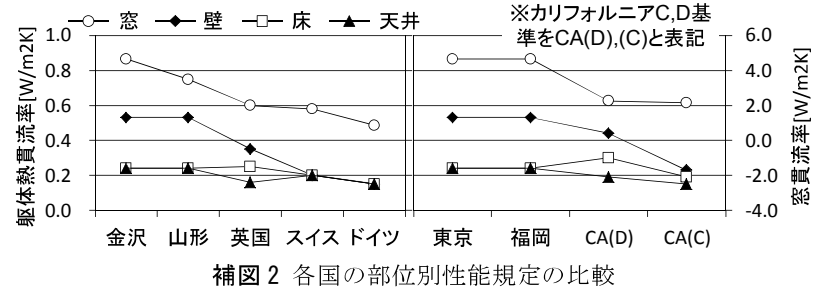

宅 $\left(120 \mathrm{~m}^{2}\right)$ の内部発熱は調理 $125 \mathrm{~W}$, 家電 $203 \mathrm{~W}$, 換気 $53 \mathrm{~W}$, 照明 $126 \mathrm{~W}$, 人体 $160 \mathrm{~W}$ と打ち分けられ，667W/棟 ${ }^{17}$ であり，計算モデルが $46.1 \mathrm{~m}^{2}$ のため, $256 \mathrm{~W} /$ 棟であるとし，計算モデルが二層の住宅であるため， $125 \mathrm{~W} /$ 層で妥当と考えた，換気回数を 0.125 回 $/ \mathrm{h}$ としたのは, 今回は, 熱交換効率を $75 \%$ と仮定すると, 換気回数 0.5 回 $/ \mathrm{h}$ を確保していても, 0.125 回/ $\mathrm{h}$ 相当の換気負荷となるためである. 本計算モデルにおける透 過日射の配分は室のプロポーションを考慮しないため, $1 / 2$ を床に, $1 / 2$ を床以外の表面に配分する 18)ものとした．また，多数の条件をシミュ レーションすることから，計算時間間隔を 1 時間とし，PCM のモデル は, 本文 5 ページ 6 行目に明記した過冷却の動作ロジックを省略するこ とで, 計算負荷を軽減した。

注7）本来, 居住者の温熱環境評価の観点からは空気温度ではなく放射環境を 考虑した作用温度のような指標で評価するべきであるが，シミュレーシ ヨンはすべて非暖房で行っており空気温度と放射温度とに差が無いこ とから，空気温度で評価することとしている，なお，東京都東京地点の 気象データで南空面積率 $60 \%, \mathrm{Q}$ 值 5.0 という条件で空気温度基準の許 容時間率と作用温度基準の許容時間率を比較したところ，30.9\% と $31.0 \%$ のうに違いはわずかであった。また $17^{\circ} \mathrm{C} \sim 28^{\circ} \mathrm{C}$ という温度範 囲については, ASHRAE の Graphic Comfort Zone Method ${ }^{19}$ における, 作用温度で $20.8^{\circ} \mathrm{C} \sim 28.2^{\circ} \mathrm{C}$ が予測不満足者率 $20 \%$, Adaptive Model に おける，作用温度で $17.5^{\circ} \mathrm{C} \sim 24.5^{\circ} \mathrm{C}$ が予測不満足者率 $20 \%{ }^{20}$ ) というこ とを鑑み，室内環境として許容できる範囲であると考え，「許容時間率」 という言葉を用いた。

注8）実際の設計では，本研究で提案する評価法で基本的な仕様を決定した住 宅についてさらに暖房負荷計算を実施することで省エネルギー効果の 試算も可能である. しかし熱負荷計算は一般の設計者にとってハードル が高く時間もかかるため, 本研究提案の線図を用いた許容時間率による 評価は住宅の太陽熱暖房方式の一般化に向け有用と筆者らは考える.

注9）東側に空を設けたモデルと, 南空換算率の計算によって同等の南空を設 けたモデルの許容時間率の比較を行った時, 誤差が $5 \%$ 以内に収まった ため,この手法で評価において十分な精度が得られると確認した。

注10) $\mathrm{Q}$ 值の汎用式は左記の補式 $1 \sim 3$ (記号は式 5 と同様)に示す手順で展開を 行い, 式 5 を導いた。

注11) 各国の省エネルギー基準における躯体・空の熱貫流率の比較は左図の通 りで, 参照した基準を補表 1 に，性能規定の比較を補図 2 にまとめた。

\section{参考文献}

1) 株式会社 住環境計画研究所 : 家庭用エネルギーハンドブック (2009 年 版), 2009.2

2）伊藤直明, 須永修通 : ダイレクトゲインシステムにおける熱容量と期間 補助暖房量に関する実験的研究, 室内気候調整における熱容量に関す る研究(2), 日本建築学会計画系論文報告集, 第 397 号, pp.38-47, 1989.3

3）武政孝治, 小玉祐一郎 : 図表を用いたパッシブソーラーシステムの暖房 性能予測(6)実用的な評価手順の提案, 日本建築学会大会学術講演梗概 集, D-2, pp. 537-538, 2003.7

4) 川井昌裕, 横尾昇剛, 坂本賢一, 岡建雄 : 砕石を利用したダイレクトグ インシステムの研究, 空気調和・衛生工学会論文集, (68), pp.45-53, 1998.1

5）近藤武士，射場本忠彦，坪田祐二，鎌田元康：潜熱蓄熱壁体による躯体 蓄熱システムに関する研究：潜熱蓄熱ボードの性能把握および適用効 果の検討, 日本建築学会計画系論文集, 第 540 号, pp.23-29, 2001.2

6) 佐藤友紀, 尾崎明仁, 中村哲己, 林禎彦, 石黒成紀: 潜熱蓄熱内装建材に よる暖房負荷の削減勃果に関する研究，模型箱実験・試験家屋実験およ び数值シミュレーションによる検討, 日本建築学会環境系論文集, 第 77 巻, 第 678 号, pp.651-659, 2012.8

7) A.K. Athienitis, C. Liu, D. Hawes, D. Banu, D. Feldman : Investigation of the thermal performance of a passive solar test-room with wall latent heat storage, Building and Environment, Volume 32, Issue 5, pp.405-410, 1997.9

8) F. Kuznik, J. Virgone : Experimental assessment of a phase change material for wall building use, Applied Energy, Volume 86, Issue 10, pp.2038-2046, 2009.10

9）金秀耿, 金田一清香, 赤嶺嘉彦, 前真之, 坂本雄三:温水ヒートポンプを 
用いた省エネルギー型床暖房システムに関する研究, 第 1 報 床暖房パ ネルの放熱特性の評価, 日本建築学会環境系論文集, 第 74 巻, 第 637 号, pp.379-387, 2009.3

10) 福本雅彦, 星川力, 川島宏起, 河野良坪, 佐藤誠, 高瀬幸造, 菱田哲也, 金秀耿, 赤嶺嘉彦, 前真之, 坂本雄三 : ヒートポンプと日射利用による 快適性の高い省エネ型蓄熱式床暖房の研究開発，その 11 . 日射の効率 的利用を目的とした PCM パネルの性能予測シミュレーション, 日本建 築学会大会学術講演梗概集, D-2, pp.505-506, 2011.7

11）金秀耿, 河野良坪, 佐藤誠, 金田一清香, 赤嶺嘉彦, 前真之, 坂本雄三： 日射ダイレクトゲインとヒートポンプを利用した蓄熱式床暖房システ ムの省エネルギー性能(第 1 報)実験システムの紹介と取得日射量の検証, 日本建築学会環境系論文集, 第 76 巻, 第 660 号, pp.169-176, 2011.2

12) Helmut E. Feustel : Thermal Performance of Phase Change Wallboard for Residential Cooling Application, Environmental Energy Technologies Division, Lawrence Berkeley National Laboratory, 2007

13）落合奈津子, 相良和伸, 山中俊夫, 甲谷寿史： PCM を組み込んだソー
ラーチムニーの換気性能に関する基礎的研究 : (その 6)換気量予測モデ ルにおける PCM の過泠却現象に関する検討, 日本建築学会近畿支部研 究報告集, 環境系, (48), pp. 221-224, 2008.5

14）日本建築学会：拡張アメダス気象データ 1981-2000, 2005

15) 田中俊六, 岩田利枝, 寺尾道仁, 武田仁, 土屋喬雄 : 最新建築環境工学 改定 3 版, 2006.3

16）財団法人 建築環境・省エネルギー機構 : 住宅の省エネルギ一基準の解 説，第 3 版, 2011.11

17）一般財団法人 建築環境・省エネルギー機構 : 平成 25 年省エネルギー 基準に準拠した 算定・判断の方法及び解説 II 住宅, 2013.11

18）株式会社 山内設計室: AE-SIM/HEAT 操作マニュアル Ver.3, 2006.09

19) ANSI/ASHRAE Standard 55-2010: Thermal Environmental Conditions for Human Occupancy, pp.5-6, 2010

20) ANSI/ASHRAE Standard 55-2010: Thermal Environmental Conditions for Human Occupancy, pp.11-13, 2010

(2013年 9 月 8 日原稿受理, 2014年 8 月 6 日採用決定) 